\title{
THE WRETCHED OF THE AFRICAN EARTH. AN ATTEMPT AT DECONSTRUCTING THE STEREOTYPE OF AFRICANISED MIGRATION DESTINED FOR EUROPE
}

\author{
BŁAŻEJ POPŁAWSKI ${ }^{1} \&$ CYPRIAN ALEKSANDER KOZERA ${ }^{2}$ \\ ${ }^{1}$ Polish Africanist Society, Krakowskie Przedmieście 26/28, 00-927 Warszawa. The Department of \\ languages and culutures of Africa, University of Warsaw. Poland. ORCID: 0000-0001-5171-8192, Email: \\ blazej.poplawski@gmail.com \\ 2 The National Defence University, al. gen. A. Chruściela 103, 00-910 Warszawa-Rembertów, Poland. \\ ORCID: 0000-0001-8620-9849, Email: kozeracyprian@gmail.com
}

ABSTRACT: The aim of the article is to deconstruct the Africanization of migration destined for Europe, to disprove several cognitive scripts on migration from Africa, most frequently quoted in the conservative media discourse. In the introduction, the migration of Africans destined for Europe in relations to the migration of Asians via Africa destined for Europe were characterized inter alia on the basis of the official documents, UNHCR and FRONTEX reports. Then, the dynamics of transcontinental and intra-Africa migrations - in synchronous and diachronic approach, with the reference to the research results of scholars specialized in the demography, social policy, history of migration - were discussed. Finally, the cultural meanings of migration among Africans is presented.

KEYWORDS: migration, Africans, discourse, stereotype

\section{INTODUCTION}

According to the survey conducted by the International Organization for Migration, since the end of the Cold War the number of African migrants living outside of the region has more than doubled, with the growth in Europe most pronounced (World 
Migration Report 2018: 44). Authors of this report have paid close attention to the lack of the reliable statistics confirming how many Africans migrated to Europe. On the contrary, there are lots of pseudo-statistical summaries describing the scale of migration in current political commentators' statements. Moreover, this non-scientific manner is overexploited in the official parliamentary discourse- mostly by rightwing 'conservative' politicians all over Europe. Theses groups have created an image of growing threat from the waves of African migrants, massively and illegally crossing the Mediterranean Sea. This perception is embroiled in numerous postcolonial stereotypes, in which "The Wretched of the African Earth" - to travesty the title of the significant book by Frantz Fanon - are exposed to protectional subjection, sometimes demonised, and not that seldom - even animalised (Ząbek 2007). In such approach Europeans' Occidentalist fears and prejudices against "the Aliens", are reflected. Yet, it specifically reveals the lack of knowledge about the context in which Africa-Europe migration occurs. It is, as well, a result of the Global North's policies towards the South, that Zygmunt Bauman called securitisation, which relies on explaining political problems by referring to the security-related discourse: "Securitisation - it is a magic trick, and this is what it is supposed to be. It depends on shifting our attention from problems, that governments do not want to, or cannot, deal with, to issues, that governments can present - daily, and on thousands of screens - as the issues efficiently solved, and sometimes even favourably" (2016: 38).

Therefore, the aim of the article is to deconstruct - or at least to make an attempt at doing so - the stereotype of Africanisation of migration destined for Europe. Thus, the authors intend to abolish several most frequently quoted cognitive scripts and "epitomes" related with African migration to Europe visible in both liberal and conservative media discourse: share of Africans among migrants travelling to Europe, the scale of intra-Africa and transcontinental migrations, and cultural meaning of migration to Africans themselves.

\section{METHODOLOGICAL APPROACHES}

Teun A. van Dijk, a prominent scholar in the fields of text linguistics, and discourse analysis, in one of his researches stated: "Closely related to these conservative and more liberal ideologies are the ideologies about who belong to Us, and who do not ideologies of nationalism, race and ethnicity. We have seen that much of the debate is controlled by the usual polarization, first between Us British and Them Foreigners and especially refugees, and secondly between genuine (good) and bogus (bad) refugees (2000a: 32). According to van Dijk, political discourse is eminently ideological. Van Dijk - using the Critical Discourse Analysis - have explored the relations between media and political discourse and racism in general, and between parliamentary debates in Western Europe and European racism in particular" (1997, 2002b). He pointed that Europeans - during the transnational debate concerned on migration challenges - have roughly divided into an open-armed leftist liberal camp and a right-wing conservative one. The Dutch scholar emphasizes that defining refugees as a political problem is classic topos of anti-immigrant discourse. Nowadays xenophobic attitude 
towards migrants is more associated with the conservative ideology than with the liberal background. Anti-immigrant conservative discourse gives special importance to the financial burden, the economic situation and cultural homogeneity. The liberal discourse, on the contrary, will orient to the international community and stress symbolic values such as tolerance, a good international reputation and cultural diversity.

Van Dijk, and other scholars specialized in discourse analysis (cf. Bennett 2018; Zanfrini 2019), were investigating how societal power relations are established and reinforced through language use. It is worth to transduce these sociolinguistic findings into the African context. It will allow to deconstruct as well liberal as conservative perspectives on the migration process.

\section{PROFILE OF THE MIGRANTS}

A stereotypical view of black African men attempting at crossing the Mediterranean on tiny boats to southern Italy or making a landing operation in over-loaded pontoons on rocky beaches of Greece has rather unconvincing confirmation in the statistical data gathered by the United Nations High Commissioner for Refugees (UNHCR) and by the European Border and Coast Guard Agency (FRONTEX). Migrants endeavouring to reach Europe are both and almost equally from Africa (among them the majority from so-called failed or fragile states: the Eritreans, Somalians, Egyptians, Libyans, Malians) and Asia (particularly from Syria, Afghanistan, Iraq; but also, from Pakistan and Bangladesh). It must be noted that many the left leaning newspapers tend to list exact countries of origin, while the right-wing titles are more likely to speak of general regions such as Africa, Sub-Saharan Africa, and not to list country of origin at all. It effectively serves to detach refugees from an identified country of origin. This kind of narration also "Africanizes" image of the migration (Berry, Garcia-Blanco, Moore 2015: 36).

Furthermore, share of Asians in the total numbers increases together with escalation of crises and armed conflicts on the continent's hot spots (like e.g. in Syria, from Yemen yet to be expected), and slow but steady stabilisation of the situation in the North Africa after the so-called 'Arab Spring' events. Worth noting, that increased controls on the Turkish border's forces more and more migrants from the Levant to avoid the Eastern-Mediterranean route and instead choose the Central one to Europe through the North Africa (UNHCR 2017, FRONTEX 2018).

Conducting a reliable analysis in the area of declared and practised religion by African migrants is hardly a feasible task. First of all, we lack reliable statistical data in this matter. Secondly, people asking for the political asylum often portray themselves as persecuted religious refugees - which not always is true. Thirdly - what will be also discussed later on - very often migration is connected with an identityrelated choice and allows a certain identity-based cognitive opening of migrants, i.e. facilitates conversion to a different set of believes, their 'update' in accordance with culturally new environment, or entirely abandoning religious believes. Under such circumstances, it is not possible to state that majority of migrants is religious radical, like conservatives' European politicians used to announce. It is safer to assume that 
the religious profile of migrants equals to that of their country of origin, which - as the liberal-minded media rightly point out - is in most cases multicultural, multi-ethnic, and multi-religious.

\section{DYNAMICS OF MIGRATION}

In his Introduction to the Lectures on the Philosophy of History Georg Wilhelm Friedrich Hegel stated: "Here we part with Africa, not to come back there anymore. It is not a part of the world in the historical meaning, as neither movements nor development can be perceived there" (1956: 119). Hegel's vision of Africa's stagnation and torpor, formulated two centuries ago, seems to be surprisingly enduring nowadays. Most Europeans - both liberals and conservatives - perceive Africa as a war-torn continent full of plagues and misery, a place from where people want to escape. Such perception, however, entirely marginalises dynamics of intra-continental migration, and without considering it, it is hard to properly and contextually characterise migration towards Europe.

The North Africa, due to its direct contact with the Mediterranean Sea and outcomes of the so-called Arab Spring, plays a crucial role as a transit area for migrants from the whole African continent attempting at making it to Europe. From the historical perspective, though, such migrations are hardly a novelty - they can be considered as a continuation of peoples' movements between the colonies and the colonial metropolises (cf. the Algerians leaving for France in the first half of the $20^{\text {th }}$ century).

In the West Africa, on the other hand, the phenomenon of the internal migration is dominant. It is connected to legal and economic regulations of the member-states of the Economic Community of West African States (ECOWAS), as well as the health and sanitary situation (e.g. Ebola epidemy in Guinea, Liberia and Sierra Leone in the years of 2014-2016), the state politics (e.g. civil war in Côte d'Ivoire between 2002-2007 and 2011), and traditional, ethnically-based migration chains initiated in the precolonial period (Iliffe 2011: 256).

In Southern Africa, we can observe, both, economic migrations, that are continuation of the colonial-time peoples' movements for work in mines and intensive agriculture (Iliffe 2011: 258), and politically-induced migrations (as waves of people fleeing the Zimbabwean economic collapse). In this region, the most popular host country is the Republic of South Africa (RSA) - the wealthiest Sub-Saharan state.

The greatest number of refugees - which overall figure is estimated at several up to a dozen or so million (Flahaux, De Hass 2016: 3) - lives in the Central and East Africa. This number is related with political crises affecting states situated in the African Great Lakes region (especially Ruanda, Burundi, Democratic Republic of the Congo), the youngest state of the world - South Sudan, and the Horn of Africa (Somalia, Eritrea, Ethiopia). The country accepting the higher number of refugees is Kenya, where the biggest refugees' camps are located: Dadaab and Kakuma. This region has the world's lowest development and education index, the highest poverty and corruption index, and has visible ethnical and tribal clientelism.

Disastrous quality of governance, crisis of postcolonial elites and disintegration 
of Sub-Saharan states forces some of region's inhabitants to resolve to migration as a strategy of survival ("migration for survival", Baldwin-Edwards 2006). According to Polish political scientist Robert Kłosowicz, atrophy of state institutions, civic society, and delegitimization of elites increase waves of migration. Thus, Kłosowicz claims as follows:

These people run not only from the war, but also from the extreme poverty and lack of perspectives for development and chances for a better future. They run from states of deep disfunctionality, and easiness with which they cross states borders only further prove how incapable the governments are at guarding them (Kłosowicz 2017: 224).

A conservative political scientist view on the phenomenon often reduces migration to an escape from threat. However, it is worth looking at the migratory processes in a broader context, from a perspective of mobility transformations and dynamics in Africa within last decades - like liberal politicians often do. Thus, in the last half century we can observe a rise in departures from Africa (specifically from countries of the Maghreb region and relatively developed states as Nigeria and RSA) and a growth of intra-continental migration (mostly in West Africa; to lower extent in Southern Africa, Central Africa; and the lowest in northern parts of the continent, and among countries of the greatest population and area size such as Nigeria and Egypt).

A half century ago, in times when most of the African states were just acquiring their independence, 2.8 million people was arriving to Africa, while 1.8 was leaving the continent. Intra-continental migratory scale amounted to ca. 6.2 million people. In the 1980s the number of Africans leaving their homeland tripled, while number of immigrants to Africa dropped by one-third. Simultaneously, a scale of intra-continental migration rose by almost $30 \%$. On the turn of $20^{\text {th }}$ and $21^{\text {st }}$ century, almost 9 million people was leaving Africa, while only 1.5 million was arriving, and intra-continental movements amounted to 10.5 million Africans (Flahaux and De Hass 2016: 7).

Migrations inside the continent, between multicultural countries, are frequently related to the ethnical identity of migrants, what - to some extent - looks like uniting families living in different states. For example, for decades inhabitants of Burkina Faso massively migrate towards the south, to Côte d'Ivoire, where they relatively easy find an occupation on cacao plantations. Those who migrate are mostly representatives of the Mossi ethnicity, whose members live on the both sides of the border. Despite their significant scale, it would be highly inaccurate to group these inter-state migrations together with flows of the people fleeing from war or state crisis - these Burkinabés' movements are exemplary cases of seasonal economical migration, and their scale stems from the strength of the ethnical bonds.

Another determinant of intra-continental migration is the phenomenon of the socalled 'urban magnetism' - inhabitants of less-urbanised areas are attracted to major urban areas (usually to the former colonial capitals situated on the coast, as Nigerian Lagos, Ivorian Abidjan, Tanzanian Dar Es-Salaam; Whitehouse 2012). These cities, called the "de-facto capitals", are multi-ethnic and multinational entities. For example, in Lagos, whose population exceeded 15 million people, dwell Nigerians, as well 
as migrants from Benin, Togo, Ghana, Niger and other African countries, mostly members of ECOWAS. This phenomenon is hardly unique. Similar movements are observed e.g. in the biggest European metropolises - what liberal-oriented researchers used to stress.

A significant role in increasing internal African mobility has been played by the regional organisations considered as the pillars of African economic community, especially that of the West of Africa such as ECOWAS (Lizak 2012: 377), yet also though to a lesser extent - from the south of the continent, like Southern African Development Community (SADC), Common Market for Eastern and Southern Africa (COMESA). Organisations from Eastern part of the continent, among which we can name the East African Community (EAC), are the least efficient in that field. It is worth noting that the dynamics of the migration within regional communities are to large extent dictated by the migratory policies of the most powerful state within given regional community, cf. the active role of Nigeria within the ECOWAS and RSA in SADC, or that rather limited of Kenya in EAC). Profiles of these migrations are fairly similar to these observed within the European Community among people looking for employment of studies abroad.

Here, we should note that the pace of immigration towards Africa is diminishing due to decreased numbers of people flowing from the Indian Peninsula and Lebanon, comparing to the colonial times. The Asian diaspora played an important role in the commercial, bank and service sectors. Presently, though, due to xenophobic policies of some African elites (cf. exodus of Hindu people from Uganda, or the Lebanese from Côte d'Ivoire), the Asians more and more often decide to return to their countries of origin (except for the Chinese). These processes negatively impact the economy of many African states.

Another factor that impacts the numbers of Africa-bound migration is a gradual drop of demand for qualified workers from Europe (the so-called expatriates) and restrictions of visa policies in most of Northern, Eastern and Central Africa states implemented in the second half of $20^{\text {th }}$ century. These phenomena can be tied to a sui generis anticolonial resentment observed in decisions of the African policymakers, looking for economic partners outside of the circle of the former colonial powers - for example among the BRICS states (Brazil, Russia, India, China, and South Africa).

Clear-cut categorisation of Africans' reasons for migration - both in case of intra-continental and outside-bound migration - is barely possible. Although, among reasons for migration of Africans we should underline the significance of demographic factors: progressive age structure, very high rate of natural increase (RNI), relatively low average life expectancy, high mortality rate and high number of HIV-infected (Lutterbeck 2006; Bakewell 2008). These factors ought to be taken into account while examining the migration phenomenon and its dynamics. Though, we should be very careful while using them, like conservative thinkers and publicists used to do, exclusively to create a profile of an African migrant, as it may lead to a biased outlook and stigmatisation of Africans as young and unexperienced people infected with lethal diseases or carriers of extreme ideologies.

It is the safest to conclude that among causes of migration waves, the key role is 
played by inter alia the system transformation and development pace. This perspective is more connected with liberally-oriented commentators. The push factors here are therefore the outcomes of economic policies of the authorities of African states (e.g. agriculture policy of the authorities in Harare), as well as GDP fluctuations related with market reactions on the stock exchange in London or Paris. Factors such as rising extremism and terrorism (cf. Boko Haram and as-Shabaab), coups d'état, rise in organised crime, etc. - however dreadful - are frequently exaggerated in their scope and impact in the European media discourse. Most of all, though, these phenomena should be analysed in the economical context. As a Cameroonian philosopher, Achille Mbembe stated: "local terrorism (...) is born at the crossroads of the caravan, nomadic and sedentary systems. It happens so, because the space and the people are in the constant move. The space is being cut by the movements, and at the same time, it is in the move itself" (Mbembe 2018: 61-62). For example, from the Horn of Africa people migrated much before the rise of as-Shabaab, and the terrorist activities of Boko Haram has a lower impact on migration than the country economy - more people move to Lagos in search for an employment than due to the persecution.

Let us note here, that pro-emigration policies for many decades have been supported by numerous African leaders, who considered them as a tool to reduce social tensions inside the country and limit the unemployment (Fargues 2004), or as a strategy aimed at acquiring additional EU funding, as it was the case of Libya at the beginning of $21^{\text {st }}$ century. As the result, waves of immigrants, including high-qualified workers, have been reaching Europe, what in consequence further contributed the so-called braindrain of Africa (el-Khawas 2004).

We must remember that - against the conservative media stereotypes - Africans migrate more and more often because of economic and education reasons, and their countries of destination are situated not only in Europe, but also in the North America, or in the Persian Gulf states. More and more Africans graduate from renewed universities and work for global and prestigious enterprises - these are no runaways, but rather members of the growing and aspiring middle-class (Bakewell and Jonsson 2011).

\section{RITUALISATION OF MIGRATION}

In the conservative media discourse concerning migration from Africa to Europe, the image of uncoordinated, uncontrollable and unpredictable "invasion of Barbarian hordes" flooding "the civilised world" is dominant. Such narration, reminding us colourful passages from Edward Gibbon's History of the Decline and Fall of the Roman Empire, supports stereotypes on the low life-quality of inhabitants of the "Third World", their alleged primitivism and atavism. This discourse lacks a reliable assessment of the phenomenon of migration, and hence pays no attention to the complex social, economic and cultural contexts of the process.

Presently, the majority of Africans migrating to Europe move through the Western Mediterranean route via Morocco to Spain, including via Spain's little African enclaves of Ceuta and Melilla - the number of illegal border crossings in 2018 (Janu- 
ary-October) on this route amounts to 45,924 people (FRONTEX 2018). Yet, most of the migrants used to travel via the Central Mediterranean migratory route, as it was the most accessible way to the south shores of Italy, namely the tiny island of Lampedusa, which is closer to Africa (113 km to Tunisia) than to Sicilia $(123 \mathrm{~km})$. They were called "Mediterranean boat people" (Pugh 2001), as they crossed the sea on fragile rubber pontoons, rafts, called by the Italians gommani, or little and unreliable boats, called scafi - both of them always dangerously overloaded (Forgacs 2008). In the time of the peak of the so-called migration crisis (2014-2016), the numbers amounted to over 181.000 people in 2016, out which 4579 died in this deadliest year for migrants. In these years of 2011 (the fall of the Libyan authoritarian leader, Muammar Qaddafi) to 2016, ca. 630,000 irregular migrants crossed the Mediterranean via this route to Italy, more than 13,000 died attempting to do so, and many other lost their lives trying to cross the Saharan desert (EPSC 2017). In 2018 (January-October), this route has been used by 21,575 people (FRONTEX 2018). Here, let us divide migrants into two categories: these who travel willingly (and therefore are smuggled) and those who are virtually enslaved by criminals and forced to travel to execute unpaid jobs upon their arrival (these people are trafficked; Andersson 2012). We should not therefore put all of the non-refugee migrants into the same category, as some of them may be found in the perilous conditions of modern slavery.

The price for migrants to cross the sea on a tiny boat with an engine (that often goes off during the trip - e.g. due to lack of essence, or an engine failure) cost from a few hundred to dozen or so thousand Euros - depending on smuggler, the departure spot, negotiating skills, but also nationality and ethnicity of the migrant (Di Nicola and Musumeci 2016: 62). Precise value of a place on a boat is hard to tell and assessments provided by various NGOs monitoring the scale and the phenomenon of socalled “pirogue migration” varies (Hernández-Carretero and Carling 2012).

Nonetheless, few migrants can pay for themselves, especially when they already had to have crossed the desert before reaching the North African shores. Therefore, for many of them whole families or communities collect money (Goldschmidt 2006). It is thus a societal decision, legitimised by the group (family, or the clan) from which the migrant comes. In such a context, migration is a strategy of the community to increase its well-being or even survive through the chosen one, who - in consequence - bears the weight of responsibility. It can be also a specific rite de passage for the usually young migrant - as already quoted Achille Mbembe says: "To become a man in the world is not a matter of birth, or origin, or race. It is the matter of route, movement and transformation" (Mbembe 2018: 197).

In the $21^{\text {st }}$ century, for many young Africans migration has become a fashionable cultural pattern, that leads to transformation of the social identity of the man himself, and in consequence many African communities. Wojciech Tochman and Katarzyna Boni in their reportage on migrants from the Middle East say that "[the migrants] from citizens became refugees" (Tochman and Boni 2014: 10). This observation contains not only a legal dimension, yet also an ontological and epistemological. The status of migrants is ex definitione renegotiable. Migration changes their way of perceiving the world, is a social initiation, confirmation of their maturity and independence. Phi- 
losopher Paweł Mościcki describe this phenomenon in the following words: "His [i.e. migrant] aspiration was not to overcome the strangeness, but making from it a new point of view, a new way of experiencing” (Mościcki 2017: 33). On the other hand, an Italian journalist, Stefano Liberti, observes:

Swelling with pride and cultivating their desire for revenge, the candidates to Europe [...] never felt defeated. They developed an inclination to willingly take the most difficult challenges, what is more - they were delighted with the potential obstacles in their paths. In other words, the final value of success increased correspondingly to the difficulty of achieving it. The trip to Europe was becoming an initiatory journey. [...] Additionally, it was associated with an element of revenge - for many people emigration was a compensation for wrongdoings, a type of Africa's revenge on Europe, which first exploited it and then left it to its fate (Liberti 2013: 120).

Liberti compares migrants to adventure seekers (2013: 8), and the families supporting their trips to financial (savings) cooperatives and investment funds (2013: 16). Africans' migration to Europe "start to be perceived through romantic lenses viewing it as a universe full of fantastic projections - their perilous travels become adventures, and they themselves become rallystes - the participants of Paris-Dakar Rally à rebours" (Liberti 2013: 183). A German journalist, Klaus Brinkbäumer similarly refers to the interpretation of the phenomenon through the perspective of a rite of passage by observing: "[migrants] cannot turn around, they are not allowed to. They would be rejected by their families and ridiculed in the village. Perhaps the mother would even hug them, but - stained by failure - they would feel shame. They would be like dead men alive" (Brinkbäumer 2009: 155).

Dramatic decision about leaving their homeland for Europe is motivated not only by the situation in their country, but also by a conviction that beyond the north shore of the Mediterranean Sea jobs and wealth awaits the migrants. The mass culture that creates an illusion of the Global North's wealth, contrasting it with the striking poverty of the South, plays a substantial function in rooting such topos in migrants' minds, and thus ritualising the phenomenon of migration. Mościcki, analysing the changes of migrants' perception, stated: The paradise is inter alia a specific way of montage (Mościcki 2017: 100). This montage occurs upon crumbs of knowledge, but generally upon rumours. Underlying this element of migration, Ben Rawlence in his captivating reportage entitled City of Thorns on the Kenyan refugee camps wrote: "Routes of migrations led through trails of memory, through places they knew or had visited, or somebody had told them about" (Rawlence 2017: 72).

The need of survival, or just to increase the social status, pushes Africans to departure towards Europe. Considering lingering effects of the economic crisis, especially affecting the border countries (such as Greece, Spain and Italy) this promising assumption becomes a painfully disappointing myth. Yet, it does still resonate in the minds of millions of Africans, believing that in the former colonial metropolis they can find peace and wealth. 


\section{CONCLUSION}

Identifying migrants coming from Africa with terrorists, carriers of lethal diseases who are taking over Europeans' jobs and developing the black market of goods is a common practice in the numerous European media outlets (De Hass 2008), in majority - associated with the conservative perspective. "The refugee has become - as Mościcki writes - a key figure of today's politics based on security discourse" (2017: 154). This discourse stigmatising the figure became a tool eagerly used by the populists and nationalists. Such politicians negate the posteriority of colonial relations and the tradition of peoples' movements between the metropolis and "the peripheries" of the former empires. Furthermore, they use the social discontent stemming from the experiences of economic crisis, by forging Europeans' fear of unknown into their election capital at the peril of the society itself.

Europeans' prejudices against Africans, as all stereotypes, have some cognitive component. Numerous migrants indeed find an employment in the 'grey zone', do not pay the taxes, live in suburban ghettos undermining (already dubious) urban aesthetics. Many of them emphasise "the martyrologic aspect" while concealing the real reason behind the migration, i.e. the economic one (Hamood 2006). These facts cannot be omitted. Yet, to properly research on the aetiology of movements, first we need to change the language of description, by dropping the tabloid-like conservative narration saturated with Occidentalism, and instead introducing a more liberal discourse that takes into consideration political, economic and cultural elements of the analysis (Zaccaria 2007; Aggestam, Hill 2008). After all, peoples' movements will not stop, and we should keep pace with them - at least and primarily cognitively.

FUNDING: This research received no external funding.

CONFLICT OF INTEREST: The authors declare no conflict of interest.

ACKNOWLEDGEMENTS: We would wish to express our gratitude to the participants of the 12 UNESCO Janusz Korczak Chair International Summer School - for extended discussions and valuable suggestions which have contributed greatly to the improvement of the article.

\section{REFERENCES}

Aggestam, Lisbeth and Hill Christooher. 2008. “The Challenge of Multiculturalism in European Foreign Policy.” International Affairs 84(1): 97-114.

Andersson, Ruben. 2012. "A game of risk: Boat migration and the business of bordering Europe.” Anthropology Today 28(6): 7-11.

Andrijasevic, Rutvica. 2006. "Lampedusa in Focus: Migrants Caught between the Libyan Desert and the Deep Sea.” Feminist Review 82: 120-125.

Bakewell, Oliver. 2008. "Keeping Them in Their Place: the ambivalent relationship between development and migration in Africa." Third World Quarterly 29(7): 13411358.

Bakewell, Oliver and Jonsson, Gunvor. 2011. Migration, mobility and the African city. 
Oxford: International Migration Institute.

Baldwin-Edwards, Martin. 2006. "Between a Rock \& Hard Place: North Africa as a Region of Emigration.” Immigration \& Transit Migration, Review of African Political Economy 33(108): 311-324.

Bauman, Zygmunt. 2016. Obcy u naszych drzwi. Translated by W. Mincer. Warszawa: PWN.

Bennett, Sam. 2018. Constructions of Migrant Integration in British Public Discourse. London: Bloomsbury Academic.

Berry, Mike and Inaki Garcia-Blanco and Kerry Moore, eds. 2015. Press Coverage of the Refugee and Migrant Crisis in the EU: A Content Analysis of Five European Countries. Report prepared for the United Nations High Commission for Refugees. Cardiff: Cardiff School of Journalism, Media and Cultural Studies.

Brinkbäumer, Klaus. 2009. Afrykańska odyseja. Translated by J. Czudec. Wołowiec: Czarne.

De Haas, Hein. 2008. „The Myth of Invasion: The Inconvenient Realities of African Migration to Europe.” Third World Quarterly 29(7): 1305-1322.

Di Nicola, Andrea, Giampaolo, Musumeci. 2016. Wyznania przemytników ludzi. Translated by A. Osmólska-Mętrak. Warszawa: Świat Książki.

El-Khawas, Mohamed. 2004. "Brain Drain: Putting Africa between a Rock and a Hard Place.” Mediterranean Quarterly 1(5): 37-56.

EPSC 2017. European Political Strategy Centre. Retrieved November 10, 2018 (https:// ec.europa.eu/commission/sites/beta-political/files/irregular-migration-mediterranian-strategic_note_issue_22_0_en).

Fargues, Philippe. 2004. "Arab Migration to Europe: Trends and Policies." International Migration Review 38(4): 1348-1371.

Flahaux, Marie-Laurence, Hein, De Haas. 2016. "African migration: trends, patterns, drivers.” Comparative Migration Studies 4(1): 3-25.

Forgacs, David. 2008. “The Words of the Migrant: Tales of Contemporary Italy.” Papers of the British School at Rome 76: 277-297.

FRONTEX 2018. Frontières extérieures European Border and Coast Guard Agency. November 10, 2018 (https://frontex.europa.eu/along-eu-borders/migratory-map/).

FSI 2018. Fragile States Index. November 10, 2018 (http://fundforpeace.org/fsi/data/). Goldschmidt, Elie. 2006. "Storming the Fences: Morocco and Europe's Anti-Migration Policy.” Middle East Report 239: 36-41.

Hamood, Sara. 2006. African Transit Migration through Libya to Europe: The Human Cost. Cairo: The American University in Cairo.

Hernández-Carretero, Maria., Carling, Jorgen. 2012. "Beyond "Kamikaze Migrants": Risk Taking in West African Boat Migration to Europe." Human Organization 71(4): 407-416.

Iliffe, John 2011. Afrykanie. Dzieje kontynentu. Translated by J. Hunia. Kraków: Wydawnictwo Uniwersytetu Jagiellońskiego.

Kłosowicz, Robert. 2017. Konteksty dysfunkcyjności państw Afryki Subsaharyjskiej. Kraków: Wydawnictwo Uniwersytetu Jagiellońskiego.

Liberti, Stefano. 2013. Na południe od Lampedusy. Podróże rozpaczy. Translated by Mar- 
cin Wyrembelski, Wołowiec: Wydawnictwo Czarne.

Lizak, Wiesław. 2012. Afrykańskie instytucje bezpieczeństwa. Warszawa: Wydawnictwo Naukowe Scholar.

Lutterbeck, Derek. 2006. "Policing Migration in the Mediterranean." Mediterranean Politics 11(1): 59-82.

Mbembe, Achille. 2018. Polityka wrogości. Translated by U. Kropiwiec. Kraków: Karakter.

Mościcki, Paweł. 2017. Migawki z tradycji uciśnionych. Bydgoszcz-Warszawa: Instytut Wydawniczy Książka i Prasa.

Pugh, Michael. 2001. “Mediterranean Boat People: a case for co-operation?” Mediterranean Politics 6(1): 1-20.

Rawlence, Ben. 2017. Miasto cierni. Największy obóz dla uchodźców Translated by S. Kowalski. Wołowiec: Czarne.

Tochman, Wojciech, Katarzyna, Boni. 2014. Kontener. Warszawa: Agora S.A.

UNHCR 2017. United Nations High Commissioner for Refugees. November 10, 2018 (https://data2.unhcr.org/en/documents/download/62326).

Van Dijk, Teun A. 1997. "There was a problem and it was solved. Legitimating the Expulsion of 'Illegal' Migrants in Spanish Parliamentary Discourse.” Discourse \& Society 8(4): 523-566.

Van Dijk, Teun. A. 2000a. "Political discourse and ideology." Pp. 15-34 in Anàlisi del discurs politic, edited by C. U. Lorda and M. Ribas. Barcelona: Universitat Pompeu Fabra.

Van Dijk, Teun A. 2000b. "On the analysis of parliamentary debates on immigration." Pp. 85-103, in: The semiotics of racism. Approaches to critical discourse analysis, edited by M. Reisigl \& R. Wodak. Vienna: Passagen Verlag.

Whitehouse, Bruce. 2012. Migrants and Strangers in an African City: Exile, Dignity, Belonging. Bloomignton: Indiana University Press.

World Migration Report 2018. 2018. Geneva: International Organization for Migration. Zaccaria, Paola. 2007. "New Faces, Old Masks: Borders and Confinements between the Desert and the Mediterranean Sea." Human Architecture: Journal of the Sociology of Self-Knowledge (5): 305-318.

Zanfrini, Laura. 2019. The challenge of migration in a Janus-faced Europe. Cham: Palgrave Macmillan. 


\section{BIOGRAPHICAL NOTE}

Błażej Popławski, $\mathrm{PhD}$, is a historian, sociologist and researcher of African societies.

Cyprian Aleksander Kozera, PhD, is an Africanist and a researcher at the National Defence University of Poland (a.k.a War Studies University).

OPEN ACCESS: This article is distributed under the terms of the Creative Commons Attribution Non-commercial License (CC BY-NC 4.0) which permits any non-commercial use, and reproduction in any medium, provided the original author(s) and source are credited.

ARTICLE HISTORY: Received 2019-09-29 / Accepted 2019-11-27 
